\title{
STUDIES ON THE CHEMOTHERAPY OF THE HUMAN MALARIAS. III. THE PHYSIOLOGICAL DISPOSITION AND ANTIMALARIAL ACTIVITY OF THE CINCHONA ALKALOIDS ${ }^{1,2,3}$
}

\author{
By JOHN V. TAGGART, DAVID P. EARLE, JR., ROBERT W. BERLINER, CHARLES \\ G. ZUBROD,4 WILLIAM J. WELCH,4 NANCY BOWMAN WISE, EDMOND \\ F. SCHROEDER, IRVING M. LONDON,“ AND JAMES A. SHANNON \\ (From the Department of Medicine, New York University College of Medicine, and the \\ Research Service, Third [New York University] Medical Division, \\ Goldwater Memorial Hospital, New York City)
}

(Received for publication March 12, 1947)

\section{INTRODUCTION}

The relative effectiveness of the various cinchona alkaloids in the treatment of malaria has been the subject of numerous investigations since the meeting of the Madras Commission in 1868 (1). Without exception, studies undertaken prior to the recent war involved the appraisal of the comparative antimalarial activities of quinine, quinidine, cinchonine and cinchonidine on the basis of the oral dosage administered during one or another standard therapeutic regimen. Although the conclusions derived from these studies are not in complete agreement, it has been the general impression that all four of the cinchona alkaloids possess roughly equivalent antimalarial activities.

Therefore, it is surprising that quinine alone has come into general use in the suppresssion and treatment of malaria. The need for a further appraisal of the other cinchona alkaloids arose early in the course of the war because of the shortage of effective antimalarial drugs. Various cinchona barks containing the principal crystallizable alka-

\footnotetext{
1 The work described in this paper was done under a contract, recommended by the Committee on Medical Research, between the Office of Scientific Research and Development and New York University.

2 Portions of this work were presented at the meetings of the Federation of American Societies for Experimental Biology, March 11-15, 1946, Federation Proc., 1946, 5, 206 and 216.

3 The authors express their thanks to the Malaria Study Section of the National Institute of Health for editorial assistance and for arrangements in regard to the publication of this paper. They are also grateful to the Abbott Laboratories, E. I. du Pont de Nemours and Company, Inc., E. R. Squibb and Sons, Eli Lilly and Company, Sharp and Dohme, and Wyeth, Inc., for contributing toward the publication costs.

4 Captain, MC, AUS.
}

loids other than quinine were potentially available in the Western hemisphere and offered a partial solution to the acute shortage of antimalarial agents.

The studies reported in this communication are concerned with the physiological disposition, antimalarial activity and, to a lesser extent, the toxicity of the four principal cinchona alkaloids. The recent development of simple, reliable methods for estimating the concentrations of the alkaloids in biological materials permitted an examination of certain aspects of their pharmacology and therapeutic activity in terms of measured drug concentrations. Quantitative information of this type may be expected to establish a basis for the most effective use of these drugs in the treatment of malaria.

\section{MATERIALS AND METHODS}

In the estimation of the concentrations of cinchona alkaloids in plasma several general procedures were utilized. The fluorescent intensity of quinine was measured in an acidic, aqueous medium following protein precipitation with metaphosphoric acid (2), quinidine by fluorimetry after extraction of the drug into ethylene dichloride (3). Cinchonine and cinchonidine were measured by the formation of an organic-soluble, water-insoluble complex of the alkaloid with methyl orange (4). With the exception of the precipitation method, the final procedures utilized in estimating plasma drug concentrations appear to be specific for the parent compounds. Ten to 20 per cent of the total fluorescent intensity obtained when the metaphosphoric acid precipitation method is applied to human plasma is contributed by metabolic products of quinine.

The therapeutic tests with blood-induced malaria were performed in accordance with standard procedures outlined in the preceding papers $(5,6)$. Therapy was started on the fourth day after the onset of fever in vivax malaria and on the first or second day of fever in falciparum malaria. Stable plasma drug concentrations were maintained during the standard four-day (vivax) or six- 
day (falciparum) therapeutic period. The drugs were administered in soft gelatine capsules. All doses and plasma drug concentrations are reported in terms of the free base. The therapeutic results are classified as previously defined: Class $I$, indicating no certain effect from drug administration; Class II, a temporary suppression of parasitemia and/or fever; and Class III, a "permanent" effect followed by a positive reinoculation procedure to establish evidence of continuing host-susceptibility.

\section{PHYSIOLOGICAL DISPOSITION}

The studies reported in this section were directed toward a limited description of the factors entering into the physiological disposition of the cinchona alkaloids. Particular emphasis was placed on the relationship between oral dosage regimens and the resultant plasma drug concentrations. In addition, data are presented concerning the absorption of the alkaloids from the gastrointestinal tract, their distribution in the body, metabolic alteration, and excretion.

Each of the drugs was administered according to several dosage schedules for periods of four days or more. Therapy consisted of an initial priming dose, usually one-half of the total daily dose, followed by small maintenance doses at fourto eight-hour intervals. Blood samples for the estimation of plasma drug concentrations were obtained several times daily throughout the period of therapy. The mean plasma drug concentrations

TABLE I

Dosage schedules of cinchona alkaloid and resultant plasma drug concentrations

\begin{tabular}{|c|c|c|c|c|}
\hline \multirow{2}{*}{ Drug } & \multirow{2}{*}{$\begin{array}{l}\text { Total } \\
\text { daily } \\
\text { dose }\end{array}$} & \multirow{2}{*}{$\begin{array}{l}\text { Number } \\
\text { of } \\
\text { subjects }\end{array}$} & \multicolumn{2}{|c|}{$\begin{array}{l}\text { Mean plasma drug } \\
\text { concentration }\end{array}$} \\
\hline & & & Range & Average \\
\hline & $\begin{array}{c}\text { grams } \\
\text { (base) }\end{array}$ & & $m g_{.} / L$ & $m g . / L$ \\
\hline Quinine & $\begin{array}{l}0.20 \\
0.50 \\
0.75 \\
1.50\end{array}$ & $\begin{array}{r}20 \\
6 \\
9 \\
44\end{array}$ & $\begin{array}{l}1.9-5.1 \\
2.9-6.5 \\
5.5-9.5 \\
7.0-12.9\end{array}$ & $\begin{array}{l}3.3 \\
4.9 \\
6.3 \\
9.6\end{array}$ \\
\hline Cinchonine & $\begin{array}{l}0.50 \\
1.00 \\
2.00\end{array}$ & $\begin{array}{r}6 \\
13 \\
16\end{array}$ & $\begin{array}{l}<0.05 \\
0.1-0.5 \\
0.3-2.7\end{array}$ & $\begin{array}{c}<0.05 \\
0.2 \\
1.0\end{array}$ \\
\hline Quinidine & $\begin{array}{l}0.1 \\
0.6 \\
1.5\end{array}$ & $\begin{array}{r}10 \\
4 \\
3\end{array}$ & $\begin{array}{l}0.2-1.3 \\
1.4-3.3 \\
2.6-5.0\end{array}$ & $\begin{array}{l}0.7 \\
2.0 \\
3.5\end{array}$ \\
\hline Cinchonidine & $\begin{array}{l}0.3 \\
1.0 \\
2.0\end{array}$ & $\begin{array}{r}6 \\
13 \\
6\end{array}$ & $\begin{array}{l}0.8-3.2 \\
1.2-3.8 \\
2.3-9.2\end{array}$ & $\begin{array}{l}1.7 \\
2.2 \\
5.5\end{array}$ \\
\hline
\end{tabular}

referred to in this paper are the averages of the individual daily mean concentrations. The various dosage schedules and the resultant plasma concentrations of each drug are summarized in Table I.

A wide range of mean plasma drug concentrations is obtained in different individuals receiving the same oral dose of any one of the four alkaloids. However, it may be noted that quinine produces the highest plasma drug concentrations. The most striking difference is that between quinine and cinchonine. At total daily doses of approximately 1.0 gram, plasma cinchonine concentrations are generally less than 5 per cent of those of quinine. Quinidine and cinchonidine concentrations are intermediate to those of cinchonine and quinine. Note should be taken of a second important difference between cinchonine and the other three alkaloids. With increasing doses of cinchonine, the resultant plasma concentrations are increased out of proportion to the increments of dosage. With the other alkaloids, the increases are disproportionately small in relation to the dose.

Peak plasma drug concentrations are achieved within one to three hours after a single oral dose of any one of the four drugs. Single oral doses of the alkaloid frequently produce plasma drug concentrations considerably lower than those obtained with soluble salts. However, on maintenance regimens, the equilibrium plasma concentration is the same with either alkaloid or salt. The plasma drug concentrations fall fairly rapidly after the termination of therapy, so that only negligible quantities of the drugs persist in the plasma beyond 24 hours.

The absorption of the four drugs from the gastro-intestinal tract is essentially complete, insofar as less than 5 per cent of the serially administered doses can be recovered from the stools. Nor is there evidence that appreciable metabolic alteration of the alkaloids occurs during their passage through the digestive tract. Small amounts of cinchonine may be incubated with stool at $37^{\circ} \mathrm{C}$. and recovered quantitatively. That absorption from the gastro-intestinal tract is rapid and essentially complete is confirmed by the observation that plasma quinine and cinchonine concentrations obtained one to four hours after a single intravenous dose are approximately the same as when the drugs are administered by the oral route. 
TABLE II

Distribution of quinine in human blood

\begin{tabular}{c|c|c|c}
\hline \hline Patient & \multicolumn{2}{|c|}{ Quinine concentration } & $\begin{array}{c}\text { Cell quinine } \\
\text { concentration, } \\
\text { per cent of } \\
\text { plasma quinine } \\
\text { concentration }\end{array}$ \\
\cline { 2 - 4 } & Plasma & Cells & \\
& $m g . / L$ & $m g . / L$ & 18 \\
1 & 5.32 & 0.94 & 19 \\
2 & 3.97 & 0.78 & 17 \\
3 & 5.36 & 0.96 & 13 \\
4 & 8.24 & 1.05 & 18 \\
5 & 3.69 & 0.65 & \\
\hline
\end{tabular}

Each of the subjects received a single oral dose of 0.3 gram quinine hydrochloride. A specimen of blood was obtained two hours after the dose, and the plasma was promptly removed by centrifugation.

Few direct observations on the extent to which the alkaloids are localized in tissues have been possible in man. The distribution of quinine in blood was examined in five subjects two hours after a single dose of 0.3 gram (Table II). The concentration of quinine in the cellular elements of the blood was found to be less than 20 per cent of that in the plasma. Similar results were obtained with cinchonine. Thus, it is apparent that little localization of quinine or cinchonine occurs in either erythrocytes or leucocytes under the conditions of this experiment. Distribution studies in the chicken and $\operatorname{dog}(7,8)$ have shown that the alkaloid concentrations in liver, spleen and other parenchymatous tissues are approximately 10 to 30 times that in the plasma. A lesser degree of localization occurs in skeletal and cardiac muscle, brain and other tissues. In man, the apparent volume of distribution of quinine within $15 \mathrm{~min}$ utes after an intravenous dose approximates the body weight. This may be regarded as indirect evidence for the limited tissue localization of quinine.

The total urinary excretion of unaltered cinchona alkaloids amounts to less than 5 per cent of the administered drug. Various metabolic products of the alkaloids are recovered from the urine and account for an additional 65 per cent of the total dose in the case of cinchonine, 20 per cent of quinine, but less than 5 per cent of either quinidine or cinchonidine $(9,10)$. The fractions unaccounted for may represent metabolic products not readily identified. However, it is evident that renal excretion plays a minor role in regulating the plasma concentrations of the parent compounds.

In view of the essentially complete absorption, limited localization and limited excretion of the cinchona alkaloids, it becomes apparent that the fate of these drugs in the body is primarily one of metabolic alteration. As noted above, varying proportions of orally administered doses can be accounted for in the urine in the form of various metabolic products. Certain important metabolic products have been recovered from urine by selective extraction into organic solvents and isolated by means of the counter-current distribution technique (10). Tentative identification by elementary analysis and comparison with known compounds indicates that each of the four alkaloids is oxidized to the corresponding carbostyril (2-hydroxyquinoline). In some instances, oxygen appears to be added to the quinuclidine portion of the molecule (9). An enzyme which oxidizes each of the four alkaloids to its corresponding carbostyril has been isolated from rabbit liver (11). This enzyme has properties similar to, and is not dissociable from the flavoprotein liver aldehyde oxidase. However, at the present time there is no evidence that this enzyme is responsible for the oxidation of the cinchona alkaloids in man. Moreover, it appears probable that the exact metabolic pathway differs somewhat with the various alkaloids. The plasma levels of the various alkaloids achieved on maintenance dosage schedules reflect their relative rates of metabolic alteration (Table I). Consequently, the low plasma cinchonine levels obtained in man reflect a high rate of metabolic alteration rather than extensive tissue localization.

\section{ANTIMALARIAL ACTIVITY}

Each of the four cinchona alkaloids was tested for its ability to terminate acute attacks of bloodinduced malaria. The results obtained with quinine have been described in detail in the preceding papers. In McCoy vivax malaria, a mean plasma quinine concentration of $5 \mathrm{mg}$. per liter or higher, maintained for four days, permanently interrupts the erythrocytic asexual phase of the infection. Quinine concentrations between 2 and $5 \mathrm{mg}$. per liter produce a temporary suppression of parasitemia and fever, while concentrations of 
TABLE III

The relationship between dosage and plasma concentration of cinchonine and therapeutic effect in four-day tests against blood-induced $M c$ Coy vivax malaria

\begin{tabular}{|c|c|c|c|c|c|}
\hline \multirow{2}{*}{ Patient } & \multirow{2}{*}{$\begin{array}{c}\text { Daily } \\
\text { dose }\end{array}$} & \multirow{2}{*}{$\begin{array}{c}\text { Mean } \\
\text { plasma } \\
\text { cinchonine } \\
\text { concen- } \\
\text { tration }\end{array}$} & \multicolumn{3}{|c|}{ Class of therapeutic effect } \\
\hline & & & I & I1 & III \\
\hline $\begin{array}{l}\text { Str } \\
\text { Bis } \\
\text { Sjo } \\
\text { Spa } \\
\text { Erl } \\
\text { Kol } \\
\text { Fre } \\
\text { Car } \\
\text { Tho } \\
\text { Joh } \\
\text { Gri } \\
\text { Mar } \\
\text { Dai } \\
\text { Tul } \\
\text { Ant } \\
\text { Coh } \\
\text { Rei } \\
\text { Nim }\end{array}$ & $\begin{array}{c}\text { grams } \\
\text { (base) } \\
2.00 \\
2.00 \\
2.00 \\
1.00 \\
2.00 \\
1.00 \\
0.80 \\
0.75 \\
0.80 \\
1.00 \\
0.80 \\
1.00 \\
0.50 \\
0.50 \\
0.50 \\
0.50 \\
0.50 \\
0.50\end{array}$ & $\begin{array}{c}m g . / L \\
0.9 \\
0.8 \\
0.5 \\
0.5 \\
0.4 \\
0.4 \\
0.3 \\
0.3 \\
0.1 \\
0.1 \\
0.1 \\
0.1 \\
0.07 \\
<0.05 \\
<0.05\end{array}$ & & $\begin{array}{l}\mathbf{x} \\
\mathbf{x} \\
\mathbf{x} \\
\mathbf{x} \\
\mathbf{x}\end{array}$ & $\begin{array}{l}\mathbf{x} \\
\mathbf{x} \\
\mathbf{x} \\
\mathbf{x} \\
\mathbf{x} \\
\mathbf{x} \\
\mathbf{x} \\
\mathbf{x} \\
\mathbf{x} \\
\mathbf{x} \\
\mathbf{x} \\
\mathbf{x}\end{array}$ \\
\hline
\end{tabular}

less than $2 \mathrm{mg}$. per liter have no effect on the course of the disease. Approximately the same plasma quinine concentrations must be maintained for six days to produce comparable effects in malaria due to the McClendon strain of falciparum. In addition, it was demonstrated that the susceptibility of the erythrocytic phase of malaria due to a particular strain of plasmodia is independent of the mode of transmission, i.e., blood-induced or mosquito-induced. For this reason, the present studies were confined to blood-induced infections.

Table III summarizes the results of therapeutic tests with cinchonine in 18 subjects with McCoy vivax malaria. Class III effects were obtained in the 12 individuals with mean plasma cinchonine concentrations of $0.1 \mathrm{mg}$. per liter or higher. Concentrations of less than $0.1 \mathrm{mg}$. per liter were consistently associated with Class II effects. Cinchonine was administered for six days to 15 patients with McClendon falciparum malaria (Table IV). In this infection, mean plasma cinchonine concentrations of $1.0 \mathrm{mg}$. per liter or higher consistently produced Class III effects. Of six individuals with mean concentrations of 0.5 or $0.6 \mathrm{mg}$. per liter, four showed Class III effects, and two showed Class II effects. No effect could be observed in one individual with a
TABLE IV

The relationship between dosage and plasma concentration of cinchonine and therapeutic effect in six-day tests against blood-induced McClendon falciparum malaria

\begin{tabular}{|c|c|c|c|c|c|}
\hline \multirow{2}{*}{ Patient } & \multirow{2}{*}{$\begin{array}{l}\text { Daily } \\
\text { dose }\end{array}$} & \multirow{2}{*}{$\begin{array}{c}\text { Mean } \\
\text { plasma } \\
\text { cinchonine } \\
\text { concen- } \\
\text { tration }\end{array}$} & \multicolumn{3}{|c|}{ Class of therapeutic effect } \\
\hline & & & I & II & III \\
\hline $\begin{array}{l}\text { Vel } \\
\text { Nad } \\
\text { Gar } \\
\text { Jef } \\
\text { Cra } \\
\text { Car } \\
\text { Gor } \\
\text { Abb } \\
\text { Boo } \\
\text { Lok } \\
\text { Naz } \\
\text { Cue } \\
\text { Vas } \\
\text { Moc } \\
\text { Dil }\end{array}$ & $\begin{array}{c}\text { grams } \\
\text { (base) } \\
2.0 \\
2.0 \\
2.0 \\
2.0 \\
2.0 \\
2.0 \\
1.5 \\
2.0 \\
1.5 \\
2.0 \\
1.5 \\
1.5 \\
1.0 \\
1.0 \\
1.0\end{array}$ & $\begin{array}{r}m g . / L \\
2.7 \\
2.0 \\
2.0 \\
1.9 \\
1.6 \\
1.0 \\
0.6 \\
0.6 \\
0.6 \\
0.5 \\
0.5 \\
0.5 \\
0.2 \\
<0.1 \\
<0.1\end{array}$ & - $\mathbf{x}$ & $\begin{array}{l}\mathbf{x} \\
\mathbf{x} \\
\mathbf{x} \\
\mathbf{x} \\
\mathbf{x}\end{array}$ & $\begin{array}{l}\mathbf{x} \\
\mathbf{x} \\
\mathbf{x} \\
\mathbf{x} \\
\mathbf{x} \\
\mathbf{x} \\
\mathbf{x} \\
\mathbf{x}\end{array}$ \\
\hline
\end{tabular}

mean concentration of less than $0.1 \mathrm{mg}$. per liter. Quinidine was studied in nine patients with McCoy vivax malaria (Table V) and in 19 patients with McClendon falciparum malaria (Table VI). In both infections, the critical plasma quinidine concentration separating Class III and Class II effects was found to be approximately 1.0 mg. per liter.

Cinchonidine was studied in 11 patients with McCoy vivax malaria (Table VII) and in eight patients with McClendon falciparum malaria (Table VIII). The critical plasma cinchonidine concentration separating Class III and Class II

TABLE $V$

The relationship between dosage and plasma concentration of quinidine and therapeutic effect in four-day tests against blood-induced $M c$ Coy vivax malaria

\begin{tabular}{|c|c|c|c|c|}
\hline \multirow{2}{*}{ Patient } & \multirow{2}{*}{$\begin{array}{l}\text { Daily } \\
\text { dose }\end{array}$} & \multirow{2}{*}{$\begin{array}{c}\text { Mean } \\
\text { plasma } \\
\text { quinidine } \\
\text { concen- } \\
\text { tration }\end{array}$} & \multicolumn{2}{|c|}{ Class of therapeutic effect } \\
\hline & & & II & III \\
\hline $\begin{array}{l}\text { Tur } \\
\text { Swe } \\
\text { Gar } \\
\text { Fein } \\
\text { Heg } \\
\text { McL } \\
\text { Rom } \\
\text { She } \\
\text { Ped }\end{array}$ & $\begin{array}{l}\text { grams } \\
\text { (base) } \\
.24 \\
.24 \\
.24 \\
.1 \\
.24 \\
.1 \\
.1 \\
.1 \\
.075\end{array}$ & $\begin{array}{c}m g . / L \\
3.2 \\
2.2 \\
1.9 \\
1.3 \\
0.9 \\
0.8 \\
0.7 \\
0.5 \\
0.4\end{array}$ & $\begin{array}{l}\mathbf{x} \\
\mathbf{x} \\
\mathbf{x} \\
\mathbf{x}\end{array}$ & $\begin{array}{l}\mathbf{x} \\
\mathbf{x} \\
\mathbf{x} \\
\mathbf{x} \\
\mathbf{x}\end{array}$ \\
\hline
\end{tabular}


TABLE VI

The relationship between dosage and plasma concentration of quinidine and therapeutic effect in six-day tests against blood-induced McClendon falciparum malaria

\begin{tabular}{|c|c|c|c|c|c|}
\hline \multirow{2}{*}{ Patient } & \multirow{2}{*}{$\begin{array}{l}\text { Daily } \\
\text { dose }\end{array}$} & \multirow{2}{*}{$\begin{array}{c}\text { Mean } \\
\text { plasma } \\
\text { quinidine } \\
\text { concen- } \\
\text { tration }\end{array}$} & \multicolumn{3}{|c|}{ Class of therapeutic effect } \\
\hline & & & $\mathbf{I}$ & II & III \\
\hline $\begin{array}{l}\text { All } \\
\text { Win } \\
\text { For } \\
\text { Jac } \\
\text { McC } \\
\text { Sep } \\
\text { LaV } \\
\text { Wri } \\
\text { Dia } \\
\text { Bra } \\
\text { McC } \\
\text { Wil } \\
\text { Agr } \\
\text { Gra } \\
\text { Bow } \\
\text { Cib } \\
\text { Hud } \\
\text { San } \\
\text { Sei }\end{array}$ & $\begin{array}{l}\text { grams } \\
\text { (base) } \\
1.0 \\
1.0 \\
0.75 \\
0.5 \\
1.0 \\
0.5 \\
0.6 \\
0.2 \\
0.4 \\
0.4 \\
0.3 \\
0.15 \\
0.10 \\
0.7 \\
0.1 \\
0.1 \\
0.1 \\
0.1 \\
0.1\end{array}$ & $\begin{array}{c}m g . / L \\
5.0 \\
3.5 \\
3.3 \\
3.3 \\
3.0 \\
2.6 \\
1.9 \\
1.8 \\
1.6 \\
1.4 \\
1.1 \\
1.0 \\
1.0 \\
0.8 \\
0.8 \\
0.7 \\
0.6 \\
0.6 \\
0.2\end{array}$ & $\mathbf{x}$ & $\begin{array}{l}\mathbf{x} \\
\mathbf{x} \\
\mathbf{x} \\
\mathbf{x}\end{array}$ & $\begin{array}{l}\mathbf{x} \\
\mathbf{x} \\
\mathbf{x} \\
\mathbf{x} \\
\mathbf{x} \\
\mathbf{x} \\
\mathbf{x} \\
\mathbf{x} \\
\mathbf{x} \\
\mathbf{x} \\
\mathbf{x}\end{array}$ \\
\hline
\end{tabular}

effects in both infections was between 2.0 and 3.0 mg. per liter.

It is apparent that the plasma drug concentration which permanently interrupts the erythrocytic phase of either vivax or falciparum malaria differs significantly with the various alkaloids. Effective plasma concentrations of cinchonine are one-tenth to one-fiftieth those of quinine. Quinidine and cinchonidine are effective in concentra-

TABLE VII

The relationship between dosage and plasma concentration of cinchonidine and therapeutic effect in four-day tests against blood-induced McCoy vivax malaria

\begin{tabular}{|c|c|c|c|c|}
\hline \multirow{2}{*}{ Patient } & \multirow{2}{*}{$\begin{array}{l}\text { Daily } \\
\text { dose }\end{array}$} & \multirow{2}{*}{$\begin{array}{c}\text { Mean } \\
\text { plasma } \\
\text { cinchonidine } \\
\text { concen- } \\
\text { tration }\end{array}$} & \multicolumn{2}{|c|}{ Class of therapeutic effect } \\
\hline & & & II & III \\
\hline $\begin{array}{l}\text { Bur } \\
\text { Dai } \\
\text { Mur } \\
\text { Ode } \\
\text { Pow } \\
\text { Jac } \\
\text { Mul } \\
\text { Saw } \\
\text { Cur } \\
\text { Rip } \\
\text { Oli }\end{array}$ & $\begin{array}{l}\text { grams } \\
\text { (base) } \\
2.0 \\
1.0 \\
0.6 \\
0.36 \\
0.6 \\
0.6 \\
0.78 \\
0.6 \\
0.36 \\
0.36 \\
0.36\end{array}$ & $\begin{array}{c}\text { mg./L } \\
7.3 \\
3.3 \\
3.2 \\
3.0 \\
2.9 \\
2.9 \\
2.0 \\
1.7 \\
1.5 \\
1.2 \\
1.0\end{array}$ & $\begin{array}{l}\mathbf{x} \\
\mathbf{x} \\
\mathbf{x}\end{array}$ & $\begin{array}{l}\mathbf{x} \\
\mathbf{x} \\
\mathbf{x} \\
\mathbf{x} \\
\mathbf{x} \\
\mathbf{x} \\
\mathbf{x}\end{array}$ \\
\hline
\end{tabular}

TABLE VIII

The relationship between dosage and plasma concentration of cinchonidine and therapeutic effect in six-day tests against blood-induced McClendon falciparum malaria

\begin{tabular}{|c|c|c|c|c|}
\hline \multirow{2}{*}{ Patient } & \multirow{2}{*}{$\begin{array}{l}\text { Daily } \\
\text { dose }\end{array}$} & \multirow{2}{*}{$\begin{array}{c}\text { Mean } \\
\text { plasma } \\
\text { cinchonidine } \\
\text { concen- } \\
\text { tration }\end{array}$} & \multicolumn{2}{|c|}{ Class of therapeutic effect } \\
\hline & & & II & III \\
\hline $\begin{array}{l}\text { Smi } \\
\text { Har } \\
\text { Cha } \\
\text { Nap } \\
\text { Joh } \\
\text { Cho } \\
\text { Smi } \\
\text { Jim }\end{array}$ & $\begin{array}{c}\text { grams } \\
\text { (base) } \\
1.0 \\
1.0 \\
0.6 \\
0.6 \\
0.6 \\
0.6 \\
0.6 \\
0.4\end{array}$ & $\begin{array}{c}\text { mg./L } \\
5.2 \\
3.1 \\
2.8 \\
2.4 \\
2.0 \\
1.9 \\
1.8 \\
1.3\end{array}$ & $\begin{array}{l}\mathbf{x} \\
\mathbf{x} \\
\mathbf{x} \\
\mathbf{x}\end{array}$ & $\begin{array}{l}\mathbf{x} \\
\mathbf{x} \\
\mathbf{x} \\
\mathbf{x}\end{array}$ \\
\hline
\end{tabular}

tions one-fifth and one-half, respectively, those of quinine. However, a final appraisal of the comparative effectiveness of the various alkaloids requires some consideration of the dosage regimens which yield the effective plasma drug concentrations. It was noted in the preceding section that a given dosage regimen results in very different plasma concentrations of the various alkaloids. Therefore, Table IX summarizes the minimal plasma drug concentrations required for Class III effects in McCoy vivax malaria and the approximate daily doses of the alkaloids which yield these critical concentrations. On this basis of comparison, it may be concluded that the antimalarial activities of the four alkaloids are of the same order of magnitude. Quinidine is approximately twice as active as quinine, while cinchonine and cinchonidine are about one-half as active as quinine. A striking deviation from these generalizations is the relatively greater resistance of $\mathrm{McClendon}$ falciparum to cinchonine therapy. However, these findings provide a general confirmation of numerous previous studies.

The extremely low plasma concentrations of cinchonine which are effective in vivax malaria prompted an examination of the antimalarial activity of cinchonine carbostyril, the principal metabolic product present in plasma and recoverable from urine. Therapeutic tests were performed in five patients with $\mathrm{McCoy}$ vivax malaria (12). One Class III effect was obtained at a mean plasma carbostyril concentration of $3.4 \mathrm{mg}$. per liter. Class II effects occurred at concentrations of 2.0 and $1.3 \mathrm{mg}$. per liter, and no effect was 
TABLE IX

Relative activity of the four major cinchona alkaloids

\begin{tabular}{l|c|c|c}
\hline \multicolumn{1}{c|}{ Alkaloid } & $\begin{array}{c}\text { Mean } \\
\text { plasma } \\
\text { concentra- } \\
\text { tion for } \\
\text { class III }\end{array}$ & $\begin{array}{c}\text { Approximate } \\
\text { daily } \\
\text { dose }\end{array}$ & $\begin{array}{c}\text { Quinine } \\
\text { equivalent }\end{array}$ \\
\hline & & $\begin{array}{c}\text { grams } \\
\text { (base) }\end{array}$ & \\
Quinine & 5.0 & 0.50 & 1 \\
Quinidine & 1.0 & 0.25 & 2 \\
Cinchonine & 0.1 & 1.00 & $\frac{1}{2}$ \\
Cinchonidine & 2.5 & 1.00 & $\frac{1}{2}$ \\
\hline
\end{tabular}

demonstrable in two patients with concentrations of 1.1 and $0.7 \mathrm{mg}$. per liter. A daily oral dose of 3.0 grams of the carbostyril was required to produce the Class III effect. The suppressive antimalarial activity of the carbostyril is, therefore, much less than that of cinchonine itself. Since, dose for dose, the same plasma carbostyril concentration is obtained whether cinchonine or its carbostyril is administered (12), it appears that this metabolic product contributes little to the antimalarial effect obtained with cinchonine.

\section{TOXICITY}

No attempt was made to appraise the relative toxicities of the various cinchona alkaloids in man. However, several incidental observations during studies of physiological disposition and antimalarial activity are worthy of mention. Typical cinchonism occurred frequently during the routine administration of quinine. Tinnitus and impairment of hearing rarely occurred at plasma quinine concentrations of less than $10 \mathrm{mg}$. per liter. Approximately half of the individuals receiving total daily doses of 1.5 grams of quinine complained of these symptoms. Frank idiosyncracy to quinine was noted in only one of several hundred patients receiving quinine. The hypersensitivity was manifested by extreme flushing of the skin and intense generalized pruritus following small doses administered either orally or by intravenous injection.

The majority of patients receiving 3.0 to 4.0 grams of cinchonine daily experienced blurring of vision, dizziness, drowsiness, marked dryness of the mouth, and constipation. In addition, acute urinary retention occurred in several instances and necessitated catheterization. Daily doses of
2.0 grams or less produced none of these unpleasant side-effects.

No evidences of toxicity were encountered at total daily doses of 2.0 grams of cinchonidine or 1.0 gram of quinidine.

\section{DISCUSSION AND SUMMARY}

It is evident from the data presented that any one of the four cinchona alkaloids will be generally effective in the management of clinical attacks of malaria. Totaquine, U.S.P., and other similar preparations, are cheap and available in abundance. These contain varying proportions of each of the cinchona alkaloids and should be useful antimalarials unless the activities of the alkaloids are not additive. There is definite evidence that the effect of combinations of the different cinchona alkaloids is additive, both in the avian malarias (13), and in vitro against falciparum parasites (14). Totaquine has been utilized rather extensively in many endemic regions and has been reported to be effective. However, until recently, there was no definitive assay of the toxicity and antimalarial activity of this type of preparation (15).

The data also indicate the importance of the various factors which determine the overall physiological disposition of each cinchona alkaloid. The cinchona alkaloids are localized in the tissues to some extent, but not nearly as much as is quinacrine (16) and the 4-aminoquinolines (17), and there is no accumulation of the drugs in the body. The combined rates of metabolism and excretion of the alkaloids are such that dosage every six hours is required to assure the maintenance of effective plasma drug levels. Consequently, it would be unlikely that the cinchona alkaloids could be as effective or as simply administered for suppressive purposes, as can some of the newer synthetic antimalarial agents which can be given at weekly intervals.

The effective plasma level of cinchonine is considerably lower than that for any of the other cinchona alkaloids. However, its metabolism proceeds at such a rapid rate that plasma drug levels achieved on cinchonine dosage are also lower than those of the other alkaloids. Since the first metabolic product of cinchonine is its carbostyril, it was possible that blocking the 2 position might re- 
sult in a compound that would be metabolized at a slower rate and which, therefore, might be a more effective antimalarial agent. This was not attempted with cinchonine, but the line of reasoning led to the development of a new series of synthetic compounds that were found to be active antimalarial agents. These compounds, 2phenyl quinoline methanol derivatives, are readily synthesized but do not possess the advantages inherent in quinacrine and the 4-aminoquinolines (18).

\section{BIBLIOGRAPHY}

1. Madras Cinchona Commission, 1867 and 1868.

2. Brodie, B. B., and Udenfriend, S., The estimation of quinine in human plasma with a note on the estimation of quinidine. J. Pharmacol. \& Exper. Therap., 1943, 78, 154.

3. Brodie, B. B., Udenfriend, S., Dill, W., and Downing, G., A scheme for the analysis of basic organic compounds in biological tissues. 2. Estimation of fluorescent compounds. J. Biol. Chem., 1947, 168, 311.

4. Brodie, B. B., and Udenfriend, S., The estimation of basic organic compounds and a technique for the appraisal of specificity; application to the cinchona alkaloids. J. Biol. Chem., 1945, 158, 705.

5. Shannon, J. A., Earle, D. P., Jr., Berliner, R. W., and Taggart, J. V., Studies on the chemotherapy of the human malarias. I. Method for the quantitative assay of suppressive antimalarial action in vivax malaria. J. Clin. Invest., 1948, 27, Suppl., 66.

6. Earle, D. P., Jr., Berliner, R. W., Taggart, J. V., Welch, W. J., Zubrod, C. G., Wise, N. B., Chalmers, T. C., Greif, R. L., and Shannon, J. A., Studies on the chemotherapy of the human malarias. II. Method for the quantitative assay of suppressive antimalarial action in falciparum malaria. J. Clin. Invest., 1948, 27, Suppl., 75.

7. Kelsey, F. E., Oldham, F. K., and Geiling, E. M. K.,
Studies on antimalarial drugs: The distribution of quinine in tissues of the fowl. J. Pharmacol. \& Exper. Therap., 1943, 78, 314.

8. Hiatt, E. P., and Quinn, G. P., The distribution of quinine, quinidine, cinchonine, and cinchonidine in fluids and tissues of dogs. J. Pharmacol. \& Exper. Therap., 1945, 83, 101.

9. Brodie, B. B., Baer, J. E., and Craig, L. C., Cinchona alkaloids: 4. Metabolic products in human urine. Federation Proc., 1946, 5, 168.

10. Craig, L. C., Identification of small amounts of organic compounds by distribution studies: II. Separation by counter-current distribution. J. Biol. Chem., 1944, 155, 519.

11. Knox, W. E., The quinine-oxidizing enzyme and liver aldehyde oxidase. J. Biol. Chem., 1946, 163, 699.

12. Earle, D. P., Jr., Welch, W. J., and Shannon, J. A., Studies on the chemotherapy of the human malarias. IV. The metabolism of cinchonine in relation to its antimalarial activity. J. Clin. Invest., 1948, 27, Suppl., 87.

13. Bratton, A. C., Jr., Continuous intravenous chemotherapy of Plasmodium lophurae infection in ducks. J. Pharmacol. \& Exper. Therap., 1945, 85, 103.

14. Berliner, R. W., Unpublished observations.

15. Green, R. A., Totaquine in the treatment of malaria. Bull. U. S. Army Med. Dept., 1945, 51, No. 84.

16. Shannon, J. A., Earle, D. P., Jr., Brodie, B. B., Taggart, J. V., and Berliner, R. W., The pharmacological basis for the rational use of atabrine in the treatment of malaria. J. Pharmacol. \& Exper. Therap., 1944, 81, 307.

17. Berliner, R. W., Earle, D. P., Jr., Taggart, J. V., Zubrod, C. G., Welch, W. J., Conan, N. J., Bauman, E., Scudder, S. T., and Shannon, J. A., Studies on the chemotherapy of the human malarias. VI. The physiological disposition, antimalarial activity, and toxicity of several derivatives of 4aminoquinoline. J. Clin. Invest., 1948, 27, Suppl., 98.

18. Wiselogle, F. Y., editor, A Survey of Antimalarial Drugs, 1941-1945. J. W. Edwards, Ann Arbor, 1946. 